\title{
Consolidation of Stakeholders' Initiatives to Mitigate Adverse Impacts of Climate Change in Nepalese Context
}

\author{
Rabindra Man Tamrakar \\ Chief Survey Officer \\ Survey Department
}

\section{Keywords}

Green House Gases (GHG), Climate Change, MoLRM, Land Policy, Land Use Policy

\begin{abstract}
Although Nepal contributes very low emissions of Greenhouse Gases (GHGs) compared to the developed nations, it is the fourth most vulnerable country in the world due to the effects of climate change. These effects have already lead to more natural disasters, loss of biodiversity, increase in mountain snow melt, uncertainty in precipitation, shortage of food, water and energy etc. resulting in devastating impacts on the life of people living in both mountain and plain areas. Climate change therefore is the vital issue in the country. Understanding the potential impacts of climate change, Government of Nepal since last two decades has taken significant initiatives in response to the effects of climate change including the participations in international conventions, the approval of Climate Change National Policy 2067 (2010), and establishment of a high level Climate Change Council (CCC) under the chairmanship of the Rt. Hon'ble Prime Minister of Nepal. In addition, The Ministry of Environment, Science and Technology (MoEST), being the National Designated Authority (DNA) in Nepal for United Nation Framework Convention on Climate Change (UNFCCC), has executed several programmes and projects related to mitigation and adaptation of climate change effects including Clean Development Mechanism (CDM) projects and National Adaptation
\end{abstract}

Programme of Action (NAPA). International Nongovernmental Organizations such as UNFCCC, DANIDA, DFID, UNEP, UNDP, UN-HABITAT, World Bank, Food and Agricultural Organization (FAO), Asian Development Bank (ADB) etc. as well have carried out numerous climate change projects and activities in Nepal in conjunction with various government agencies.

Studies have revealed that the major sources of GHGs are from the burning of fossil fuel (75\%), land use changes (20\%), and other sources (5\%). It has also been postulated that the effects of climate change can be significantly reduced through the implementation of land use policy and activities. Ministry of Land Reform and Management (MoLRM), Government of Nepal (GoN) is the central agency in Nepal dealing with the formulation and implementation of land related policies and activities in the country. MoLRM has commenced to formulate the National Land Policy and has planned to complete it at the end of fiscal year 069/70. This policy will definitely assist in mitigating the effects of climate change in the country. Another essential policy for the mitigation of the impacts of climate change in the country is National Land Use Policy which was prepared by MoLRM and has been approved by GoN in 2012, but it is yet to be implemented. One of the important policies that it has focussed on for the mitigation of climate change effects is to increase the present forest coverage to $40 \%$ of the total area of the country while protecting the government land by forestation and plantation programmes on degraded lands. 


\section{Introduction}

Land is the mainstay of human life as it provides food, shelter, clothing and energy required for the people, without the proper management of land, it is not possible to improve the economy of a country. Nepalese economy depends primarily on agriculture, which employs more than 65.7 percent of the total population contributing nearly 32.7 percent of GDP. The population growth rate is about 1.35 percent per annum while the increase in food grain production is merely 2.8 percent (CBS, 2012). During the past few decades, the studies have shown that effects of climate change in Nepal have resulted in loss of agricultural production from the drought, depletion of biodiversity, disruptions of water supply to urban areas, spread of tropical diseases, health damage and even deaths from heat waves, spreads of harmful pests, etc. Moreover, disruptions of weather patterns caused by the climate change will lead to the increase in floods, glacial lake outbursts, hurricanes and other extreme events with the loss of lives and properties.

The atmosphere is largely transparent to incoming short-wave (or ultraviolet) solar radiation, which is absorbed by the Earth's surface. Much of this radiation is then re-emitted as heat energy at longwave, infrared wavelengths. Some of this energy escapes back into the space and due to the presence of Greenhouse Gases (GHGs - i.e. Carbon Dioxide $\left(\mathrm{Co}_{2}\right)$, Methane (NH4), Nitrous Oxides $\left(\mathrm{N}_{2} \mathrm{O}\right)$, Ozone $\left(\mathrm{O}_{3}\right)$, Hydrophloro Carbon (HFC), Perfloro Carbons $\left(\mathrm{PF}_{6}\right)$, Sulphur Hexafloride $\left(\mathrm{SF}_{6}\right)$ and Chloro-fluoro Carbons) in the earth's atmosphere, heat energy is trapped inside. Earth as well emits terrestrial radiation. There is a delicate balance between solar and terrestrial radiation which keep the earth's environment warm. If there were no GHGs, the temperature of earth would be inhabitable. The presence of natural GHGs is therefore important for maintaining an optimum temperature and has helped in survival on earth. However, due to the increasing concentration of anthropogenic GHGs (mostly $\mathrm{Co}_{2}, \mathrm{NH}_{4}$, and $\mathrm{N}_{2} \mathrm{O}$ ) resulted from the human activities on earth, additional heat energy is trapped in the atmosphere. It is estimated that more than $75 \%$ of GHGs is generated from the burning of fossil fuel, $20 \%$ from land use changes, and 5\% from other sources. Effect of this heat trapping due to the increasing presence of GHGs in the atmosphere is known as greenhouse effect. This effect causes global warming and its main consequence is the climate change.

Even though Nepal contributes very low emissions compared to other developed nations, it is the fourth most vulnerable country among the 170 countries in the world (with Bangladesh and India ranking first and second respectively) due to the effects of climate change. These effects lead to more natural disasters, species migration, loss of biodiversity, changes in vegetation cover, increase in mountain snow melt, uncertainty in precipitation, shortage of food, water and energy etc. resulting in devastating impacts on the life of people living in both mountain and plain areas (WFP, 2009). Climate change has therefore become a priority issue in Nepal.

Understanding the potential impacts of climate change, Government of Nepal (GoN) since 1990s has taken important steps in response to the effects of climate change and has participated in international conferences and conventions. In addition, GoN has approved the Climate Change National Policy 2067 (2010) and has established a high level Climate Change Council under the chairmanship of the Rt. Hon'ble Prime Minister of Nepal. Likewise, the Ministry of Environment, Science and Technology (MoEST), being the National Designated Authority in Nepal for UNFCCC, has executed several programmes and projects related to mitigation and adaptation of climate change effects (Clean Energy Nepal, 2002). International non-governmental organizations as well have carried out numerous climate change projects and activities in Nepal in conjunction with various government agencies.

Furthermore, there is a strong relationship between sustainable economic development and climate change. Climate change issues however have not become sufficiently prominent in government development plans. In order to increase the economy with environmental protection, the country must reduce its emissions through the proper implementation of land related policies including climate change policies, National Land Policy, 
National Land Use Policy etc. These policies as well deal with the issues on land use changes which contribute nearly $20 \%$ total GHGs emission.

Ministry of Land Reform and Management (MoLRM), GoN is the central agency in Nepal dealing with the formulation and implementation of land related policies and activities in the country. Moreover, it is the core ministry looking after the land administration and management activities, and is responsible for ensuring efficient and effective administration and sustainable management of available land resources. With the implementation of land related policies and use of land information systems produced by various agencies under MoLRM, the impacts of climate change in Nepal could be reduced with the significant increase in sustainable economic and social development of the country.

\section{Sources of GHGs and Climate Changes}

Emissions of three principle GHGs, which include carbon dioxide $\left(\mathrm{CO}_{2}\right)$ methane $\left(\mathrm{NH}_{4}\right)$ and nitrous oxide $\left(\mathrm{N}_{2} \mathrm{O}\right)$, cause green house effects in the atmosphere. $\mathrm{CO}_{2}$ is the major component which forms about 75 percent of the total GHGs. $\mathrm{CO}_{2}$ is mainly produced from burning of fossil fuels (such as oil, coal and gases), energy generation and transport. Annual flow of Global emission of $\mathrm{Co}_{2}$ is nearly 42 Gegatons in the year 2000. Studies reveal that rapid industrialization coupled with urbanization, excessive consumption of fossil fuels, deforestations, slash \& burning of forests, agricultural development etc. in the world over the past two centuries have resulted in significant increase of $\mathrm{CO}_{2}$ gas in the atmosphere. Before the rapid industrialization, the share of $\mathrm{CO}_{2}$ gas in the atmosphere was estimated to be $280 \mathrm{ppm}$ (parts per million) which now has increased to $430 \mathrm{ppm}$. If this trend in rising of $\mathrm{CO}_{2}$ gas continues, the level of this gas in the atmosphere is predicted to be $800 \mathrm{ppm}$ at the end of this century, which will create serious impacts on the entire earth. Concentrations of other GHG gases such as $\mathrm{NH}_{4}$ and $\mathrm{N}_{2} \mathrm{O}$ as well have significantly increased over the period. Methane which is generated from the energy industries, agricultural sources and wastes to landfills contributes about $17 \%$ of the total GHGs in the atmosphere; whereas $\mathrm{N} 2 \mathrm{O}$ produced mainly from the agricultural sources accounts for nearly $6 \%$ (NCVST, 2009).

Over the last few decades, studies have indicated that temperature of earth surface has been rising and this has caused changes in weather patterns, resulting in rise in sea level, melting of glaciers, floods, draught, loss in agricultural production etc. Meteorological measurement records show that a warming of 0.3$0.6^{0}$ Celsius (C) in global average temperature since 1860. Moreover, the global temperature has increased by $0.76^{\circ} \mathrm{C}$ during the period of 150 years (IPCC, 2007). It is also recorded that 1990 s was the warmest decade of the global surface temperature since 1850 . The studies further reveal that the global temperature could rise up to $4.5^{\circ} \mathrm{C}\left(2.4^{\circ}\right.$ to $\left.6.4^{\circ} \mathrm{C}\right)$ by sometime in the $21^{\text {st }}$ Century (IPCC, 2000). In addition, it has been suggested that warming of more than $2.5^{\circ} \mathrm{C}$ could reduce global food supplies and contribute to higher food prices (UNEP \& UNFCCC, 2002).

Effect of the climate change also causes variability in precipitation patterns leading to increased variability and uncertainty in rainfall. The study also reveals that monsoon delayed in Nepal is caused by the climate change effects. Likewise, speed and direction of wind change due to the climate change effects leading to higher risks of cyclones resulting in devastating phenomena.

\section{Scenario of Climate Change Effects in Nepal}

Based on the available information, annual Global emission of $\mathrm{Co}_{2}$ is nearly 42 Gegatons with United Arab Emirates, Kuwait, United States and Canada being ranked highest per capita $\mathrm{Co}_{2}$ emitters. The annual per capita $\mathrm{Co}_{2}$ emissions from these countries are $33.4 \mathrm{t}, 32.7 \mathrm{t}, 19.9 \mathrm{t}$ and $17.9 \mathrm{t}$ respectively. Nepal's per capita emission of $\mathrm{Co}_{2}$ ranks lowest among SAARC nations at 0.1 metric tons per year. Although the contribution of total GHG emission by Nepal to the global community is insignificant (nearly $0.025 \%$ of the total global emission) compared to the developed countries, Nepal has already encountered several negative effects due to the global climate change. Studies carried out by the Department of Hydrology and Meteorology, GoN reveal that 
average temperature in Nepal is increasing at the rate of nearly $0.06^{\circ} \mathrm{C}$ per year $\left(0.04^{\circ} \mathrm{C}\right.$ in Terai) between the period of 1977 and 1994. Another temperature analysis from 1976 to 2005 has revealed that the average temperature in Nepal has increased by $0.597^{\circ} \mathrm{C}$ per year. The projected figures for Nepal further show that average increase in temperatures of $1.2^{\circ} \mathrm{C}$ for the year $2030,1.7^{\circ} \mathrm{C}$ for 2050 and $3.0^{\circ} \mathrm{C}$ for 2100 . The temperature in the Himalayan Region, on the other hand, is increasing at a greater rate with $0.09^{\circ} \mathrm{C}$ per year, which is having severe effects on the glacial lakes, which are the main source of Nepal's water resources. It is also recorded that more temperature rises in the winter seasons than the summers (Shrestha et al., 2000). Due to the rise of temperature in the Himalayan region, Rika Samba Himalayan Glacier in the Dhaulagiri region, western part of Nepal, for example, is receding at a rate of 10 $\mathrm{m}$ per year.

People's lives and livelihoods, especially of poor and marginalized social groups such as farmers, indigenous communities, women and children in the rural areas who are least able to cope with are most at risks and vulnerable to the disasters caused by the climate change.

\section{Nepal's Initiatives in Response to the Climate Change}

Climate change is a serious issue in global scale with its effects globally in different ways and scale. Least developed countries such as Nepal are the most vulnerable ones to its impacts. Understanding the potential impacts of climate change, Nepal has therefore signed the United Nation Framework Convention on Climate Change (UNFCCC) in Rio De Janerio, Brazil in June 12, 1992 and has ratified it on 2nd May in 1994. Since then, Nepal has been regularly participating in Conference of the Parties (COP) and other subsidiary meetings. It also became party of Kyoto Protocol by submitting its instrument of Accession on September 16, 2005. Nepal is listed as the non-annex 1 party to the Protocol.

In addition to the ratification of UNFCCC, Nepal also has ratified the two other Rio Conventions: the Convention to Combat Desertification (UNCCD) and the Convention on Biodiversity (UNCBD). All conventions oblige their signatories to follow a stipulated reporting system. Nepal's national report to the UNCCD was prepared and presented in the Fourth Conference of the Parties (COP 4) in 2000.

\subsection{The Ministry of Environment in Response to Climate Change}

The Ministry of Environment, Science and Technology (MoEST) is the focal point for the UNFCCC in Nepal and is the National Designated Authority (DNA) to execute Clean Development Mechanism (CDM) projects. So far two biogas CDM projects have been approved. MoEST also has prepared the first National Communication Report of UNFCCC in 2004, outlining the GHG emission sources, possible impact areas and some adaptation measures. In addition, MoEST in conjunction with UNEP/GEF is preparing Second National Communication Report. Likewise, MoEST in cooperation with DANIDA has developed a project on "Strengthening the Capacity Building on Negotiations and COP 15 Preparation."

In November, 2008, MoEST has signed the contract with UNDP to officially start the National Adaptation Programme of Action (NAPA) formulation process in Nepal, targeting mainly to the marginalized and vulnerable communities in the country. The preparation of the NAPA is the first official initiative to mainstream adaptation into national policies and actions so as to address the adverse impacts of climate change and reduce vulnerability to changing climate and extreme events. NAPA has six basic thematic sectors; namely, Agriculture and Food Security, Forest and Biodiversity, Water and Energy, Climate Induced Disaster Public Health, Urban Development and Infrastructure. Similarly, Local Adaptation Plan of Action (LAPA) supported by DFID donor agency has been implemented in the country.

The Ministry has prepared NAPA document in 2010 with some good progress in terms of initial understanding on vulnerability context and identifies preliminary sectoral issues through the mobilization of thematic working groups. Research and Development on Climate Change unit has been established within this Ministry in Collaboration 
with universities in 2010.

GoN has enforced a variety of strategies and has to imply different policies owing the long term climatic change affects. Nepal's $9^{\text {th }}$ and $10^{\text {th }}$ Plan has emphasized several alternative energy sources to reduce the domestic use of wood and fossil fuels with more use of hydropower and bio-gas. Interim Government of Nepal has also decided to promote various CDM projects under the UNFCCC and alternative energy system in rural communities. GoN is also promoting clean energy and sustainable development in the country in order to take advantage of the CDM as a source of new investment and technology. Policies have also been implemented to import Euro-1 standard vehicles and ban on the registration of two stroke vehicles to increase the efficiency and reduce pollution from the transport sector.

National Planning Commission has as well initiated Climate Resilience Planning Process Programme with the support from ADB for the running Three Year's Plan (2010-2013). Mitigation Plan on Climate Change became the National Agenda.

\subsection{Non-Governmental Organizations in Response to Climate Change}

Government agencies along with International Non-governmental Organizations (INGOs) are regularly working for data and information generation on climate change related impacts and for raising awareness among local people. MoEST has set up Climate Change Network comprising of representatives of relevant government bodies, NGOs, civil society and experts for information and knowledge management and policy input.

In addition, Nepal has other policies and programmes for promoting clean energy. Some Non-governmental Organizations (NGO) along with the donor agencies and private organizations as well are actively involved in these programmes. For example, the Alternative Energy Promotion Centre, together with several NGOs and private companies, is promoting clean energy efficiency technologies such as biogas, micro-hydro and solar through subsidies as well as technical assistance. Moreover, Nepal is promoting electric vehicles as a promising alternative for transportation. Kathmandu now has more than 600 zero-emission electric vehicles and there is potential for a lot more, provided that the government policies are favorable.

The World Bank has also established Forest Carbon Partnership Facility (FCPF) to support developing countries in their efforts to build capacity for Reducing Emissions from Deforestation in Developing Countries (REDD) at the country level. The purpose of the facility is to assist developing countries to be ready for REDD by 2012. Nepal, after the approval of its Readiness Plan Idea Note (R-PIN) by the Bank in July 2008, has officially been selected as one of the FCPF countries. The Bank has now pledged to support Nepal for preparing Readiness Preparation Proposal (R-PP) with an aim that the country could be able to implement initially forest carbon pilot projects, and subsequently get ready for implementing larger scale incentive based forestry development and conservation program at the country level.

\subsection{Other Initiatives in Response to Climate Change}

One of the important initiatives to the climate change that GoN has carried out was the historic cabinet meeting held at Kalapani $(5,545 \mathrm{~m}$ above the sea level), the base camp of Mount Everest (8,848 m.), on December 4, 2009, which was attended by the former Prime Minister Madhav Kumar Nepal and 23 other ministers in order to draw attention of international communities towards melting of Himalayas due to climate change effects. Addressing the historic meet, the former Prime Minister said that the issues regarding climate change were not restricted only to the mountainous nations but was relevant to the whole world. He sought initiatives from the nations which produce large amounts of carbon emissions to address the issues regarding climate change at the earliest. Likewise, GoN has carried out Regional Climate Change Conference in Kathmandu in August, 2009. Similarly, GoN has included Climate Resilient Programme in the running Three Years Plan (2010 - 2013). 
In addition, GoN has constituted a high level coordination council such as the Climate Change Council (CCC) under the chairmanship of the Rt. Hon'ble Prime Minister of Nepal, and other committees including Pilot Programme on Climate Resilience Coordination Committee (PPCR), and Multi-stakeholder Coordination Committee Initiative on Climate Change (MCCICC). Major functions of $\mathrm{CCC}$ are as follows:

- Provide guidance and ensure coordination for the formulation and implementation of Climate Change related policies

- Promote Climate Change integration in longterm policies, plans and programmes

- Promote Climate Change as national development agenda

- Process for additional financial and technical support for Climate Change programmes

- Process for benefiting from international negotiations and decisions

Furthermore, the sixth meeting of CCC under leadership of former Prime Minister Madhav Kumar Nepal endorsed a document on Climate Change National Policy 2067 (2010) in the year of 2010. The draft of the Climate Change Policy 2067 has aimed at promoting development of clean energy and making economic evaluation of the impacts and possible advantage and disadvantage of the climate change. Vision of this policy is the pollution free Nepal, increase in productivity through management of resources, environment-friendly infrastructure development, reduced natural disasters, and enhanced livelihood opportunities. Major broader areas included in this policy are institutional strengthening, natural resources management, disaster mitigation and adaptation, GHG emission, pollution control and CDM, awareness capacity building and empowerment etc. This Policy 2067 was approved by the Government of Nepal in January 17, 2011.

There are other national initiatives like the Pilot Programme on Climate Resilience (PPCR) and REDD under the Ministry of Forest and Conservation. PPCR has launched stakeholders meeting in September, 2009. Likewise, with the participation of Department of Hydrology and Meteorology (DHM), the Asian Pacific Network has initiated capacitybuilding activities in Nepal; Ministry of Agriculture and Cooperative (MOAC) with the assistance from FAO has as well carried out Agriculture and Climate Change Project.

\section{Role of Ministry of Land Reform \& Management}

Ministry of Land Reform and Management (MoLRM) is the central agency in Nepal dealing with the formulation and implementation of land related policies and activities in the country. Initially, this ministry was set up in 1964 (2021B.S.) as a Ministry of Land Reform with 3 major directorates; namely, Land Reform, Cooperatives and Cadastral Survey. Since the inception of its establishment, this ministry has been taking significant responsibilities, especially in the formulation and implementation of land related policies and activities in the country.

Since last few decades effects of climate change have become a priority issue in Nepal. It has been postulated that the effects of climate change can be significantly mitigated with the proper implementation of land related policies. National Land Policy and Land Use Policy are the fundamental land related policies in the country to cope with all kinds of land problems along with the adaptation and mitigation of climate change effects.

\subsection{National Land Policy}

One of the major tools for the mitigation of climate change effects in Nepal is the implementation of National Land Policy. MoLRM has planned to prepare it at the end of fiscal year 069/70 although it has been addressed effectively in the past. In order to prepare this policy, MoLRM has carried out the first seminar on National Land Policy with the stakeholders in Kathmandu on December 24, 2012.

Land related problems have not been viewed in an integrated way in the past. Planning system of Nepal has remained sectoral. However, in the Tenth Plan (2002-2006) has clearly emphasized the formulation of land policy of the country, but it was not possible. The current Three Year's Plan (2010-2013) as well has put stress on the formulation of Land Use Policy 
and National Land Policy. The absence of integrated national land policy and land use programmes has led to unsystematic planning and development of the country with deteriorating environment and land degradation. Increment in agricultural productivity, employment generation and food security are other issues that need to be solved properly. In order to cope with all these problems, GoN has finally perceived the need of developing and implementing National Land Policy for the long term integrated land use planning and management for the sustainable use of limited land resources of the country. Maximum benefit from land resource can only be achieved by classifying land on the basis of utility and appropriateness with the implementation of such policy. This will lead to poverty alleviation, increase in crop productivity, conservation of natural resources, social and economic development of the country. This policy also will help provide opportunities for the investors, and will assist in mitigating the effects of climate change.

\subsection{National Land Use Policy}

Another essential policy for the mitigation of the impacts of climate change in the country is National Land Use Policy. Unlike the National Land Policy, this policy keeps first priority on the optimal use of land resources with secondary preference given to land ownership and tenures. In the $9^{\text {th }}$ Plan (19972002), GoN has clearly specified the land use policy in the country. The need for classification of agricultural land on the basis of land capability has been emphasized. The plan further states the need of zoning land for agriculture, forestry, residence, industrial areas, and non-agricultural purpose in order to maintain environmental balance and sustainable uses of environmental resources. Moreover, implementation of national land use programmes has been included in the $10^{\text {th }}$ Plan. Some of the programmes included in the $10^{\text {th }}$ Plan are updating land use maps, preparation of district level digital land resources GIS database, preparation of district profiles etc.

National Land Use Policy was finally approved by GoN in the year 2012 through the Cabinet Decision (April 16,2012), it has however not been implemented.
Furthermore, GoN has already included the land use acts and Formulation of Land Use Council in the modified land acts (2058 B.S.). One of the important policies that it has focused on for the mitigation of climate change effects is to increase the present forest coverage to $40 \%$ of the total area of the country while protecting the government land by forestation and plantation programmes on degraded lands. The studies reveal that the overall deforestation rate in Nepal is currently $1.7 \%$, which is well above the Asian average $(1 \%)$ and the global average (1.3\%) (MFSC, 2008). This policy also has discouraged the land fragmentation practices while encouraging the public to land consolidation. It has as well discouraged the present improper land use practices in the country. The policy has addressed to manage the mountains and hills while controlling soil erosion, which causes floods in the downstream, especially in the valleys and the Terai. There are several other essential policies that it has concentrated on, some of them include the protection of biodiversity, sustainable development of the country while mitigating the impacts of climate change, discouraging the development of residential areas under the hazardous prone zones etc. Moreover, it has emphasized to include the land use issues in the educational curriculum in order to increase the awareness in the young generation. For the optimum use of land and its resources, land use zoning policy which is included in the aforementioned policy will be imposed based on the land capability, geological structures, climatic conditions and suitability of the areas.

\subsection{Survey Department}

One of the important organizations under MoLRM for the mitigation of climate change effects in the country is Survey Department (SD) which is now recognized as a National Mapping Organization. This department established in 1957 conducts the surveying and mapping activities and has a broad multi-disciplinary resource base and produces a wide range of ground surveys, aerial photography, photogrammetry, geo-information and cadastral map products and services in order to support multi-sectoral development activities including the reduction and adaptation programmes of climate change effects. 
Moreover, SD has prepared topographic maps of the entire nation in 2001. One of the major components of these maps is the land cover information which is very useful for the estimation of forest biomass for the climate change study. Topographic maps at the scale of 1:25,000 were prepared for the Terai and the Mid Hill Regions of Nepal and are based on aerial photographs taken in 1992 and 1996 with extensive ground truthings. Topographical maps at the scale of 1:50,000 dated 1996-97 on the other hand are available for High Mountain and Himalayan Regions of Nepal. Moreover, digital data of these topographic map series are as well available from this department. These databases were created in 2002 using ARC/INFO GIS software programmes by a project under $\mathrm{SD}$ with the financial assistance from the Finish Government. These databases are valuable tools for the preparation of national forest inventory as well as for the estimation of forest biomass using GIS technology.

Likewise in 1986, Land Resources Mapping Project (LRMP, 1986) under SD has prepared Land Utilization maps at 1:50,000 scale of the entire Nepal, using 1978/79 aerial photographs with extensive ground verifications. These data have provided an opportunity to estimate forest biomass and prepare basic forest inventory of the country as well as for the study of climate change effects. LRMP data has also placed specific emphasis on forests, shrublands, agriculture, and grassland resources. Forest units have been further classified into various components including forest cover types, species associations, crown density coverage, and maturity classes. LRMP information as well was used for the preparation for the Master Plan of the Forestry Sector of Nepal in 1989.

\section{Conclusions}

Climate change is a serious issue in global scale with its effects globally in different ways and scale. Least developed countries such as Nepal are the most vulnerable ones to its effects. People's lives and livelihoods, especially of poor and marginalized social groups such as farmers, indigenous communities, women and children in the rural areas who are least able to cope with are most at risks and vulnerable to the disasters caused by the climate change. Climate change therefore has become a priority issue in Nepal. Following conclusions are drawn to lessen and adapt the adverse effects of the climate change in the Nepalese context.

- Although Government of Nepal along with several stakeholders (including INGOs in conjunction with various government organizations) have taken initiatives in response to the effects of climate change and have carried out plentiful projects and activities in Nepal, there is still a lack of consolidation of stakeholders' initiatives to mitigate and adapt the impacts of climate change.

- Moreover, there is a need of comprehensive research works, capacity building at different levels, inter-departmental coordination and focus on integrated policy on climate change and its impacts.

- Climate change issue is not only concerned to one organization such as MoEST, but to all. All the stakeholders therefore must work together in order to reduce and adapt the effects of climate change.

- There is also a need to raise awareness on climate change and global negotiations.

- Finally, since MoLRM is the central agency responsible for the formulation and implementation of all land related policies and activities in Nepal, this ministry should formulate the National Land Policy on schedule and also should implement the approved National Land Use Policy as soon as possible to mitigate the effects of climate change.

\section{References}

CBS, 2012. Statistical year book Nepal. Central Bureau of Statistics, National Planning Commission, Kathmandu, Nepal.

Clean Energy Nepal, 2002. Clean Energy Nepal's Fact Sheet \#2. Kathmandu. Nepal.

Dahal, N. 2006. Implications of Climate Change in Nepal: Some Observations and Opportunities. Paper Presented at 23rd Warden Seminar, November 2006 held in Pokhara, Nepal. 
DHM, 2007. Climatological \& Agrometereological Records of Nepal 2007, Department of Hydrology and Meteorology, Ministry of Environment, Science and Technology, Government of Nepal.

DFRS, 2010. Forest Resource Assessment (FRA) Nepal Project, Department of Forest Research and Survey, Ministry of Soil and Conversation, Government of Nepal.

Li-BIRD, 2009. Climate Change and Agrobiodiversity in Nepal, A Report Prepared for Platform for Agrobiodiversity Research in collaboration with FAO and Bioversity International. Pokhara, Nepal. $17 \mathrm{pp}$

MFSC, 2008. Forest Carbon Partnership Facility Readiness Plan Idea Note (R-PIN) Nepal.

MoEST and UNDP, 2008. National Adaptation of Programme of Action to climate change project Document. Ministry of Environment Science and Technology and United National Development Program.

NCVST, 2009. Vulnerability Through the Eyes of Vulnerable: Climate Change Induced Uncertainties and Nepal's Development Predicaments. Institute for Social and Environmental Transition-Nepal. Nepal Climate Vulnerability Study Team (NCVST). Kathmandu, Nepal.

Pokhrel, A. P., 2002. Temperature and Precipitation Trend and Its Impact in Nepal, Paper presented on First Preparatory meeting on Eighth Conference of Parties, COP 8, organized by IUCN Nepal.
Tamrakar, R.M 2012. A Prospect of Digital Airborne Photogrammetry Approach for Cadastral Mapping in Nepal. Nepalese Journal on Geomatics, MayJune, 2012, Number 11, 1-6. Survey Department, Government of Nepal, Kathmandu, Nepal.

Tamrakar, R.M 2011. Impacts of Climate Change and Remote Sensing Technology in its Mitigation Options through Forest Management. Nepalese Journal on Geomatics, May-June, 2011, Number 10, 16-21. Survey Department, Government of Nepal, Kathmandu, Nepal.

UNEP \& UNFCCC, 2002. Climate Change Information Kit. Sheet 10. United Nation Environment Programme and United Nation Framework Convention on Climate Change. WFP, 2009.

UNFCCC, 2002. Annotated Guidelines for the Preparation of National Adaptation Programmes of Action. Least Developed Countries Expert Group.

WFP, 2009. The Cost of Coping. A collision of crises and the impact of Sustained Food Security Deterioration in Nepal. United Nations World Food Programme. Nepal Food Security Monitoring System.

Wigley, T.M.L. and S.C.B. Raper. 1993. "Future Changes in Global-Mean Temperature and Sea Level," in Climate and Sea Level Change: Observations, Projections and Implications, R.A. Warrick, E. Barrow, and T.M.L. Wigley (eds.), pp.111133. Cambridge University Press, Cambridge, $424 p p$.

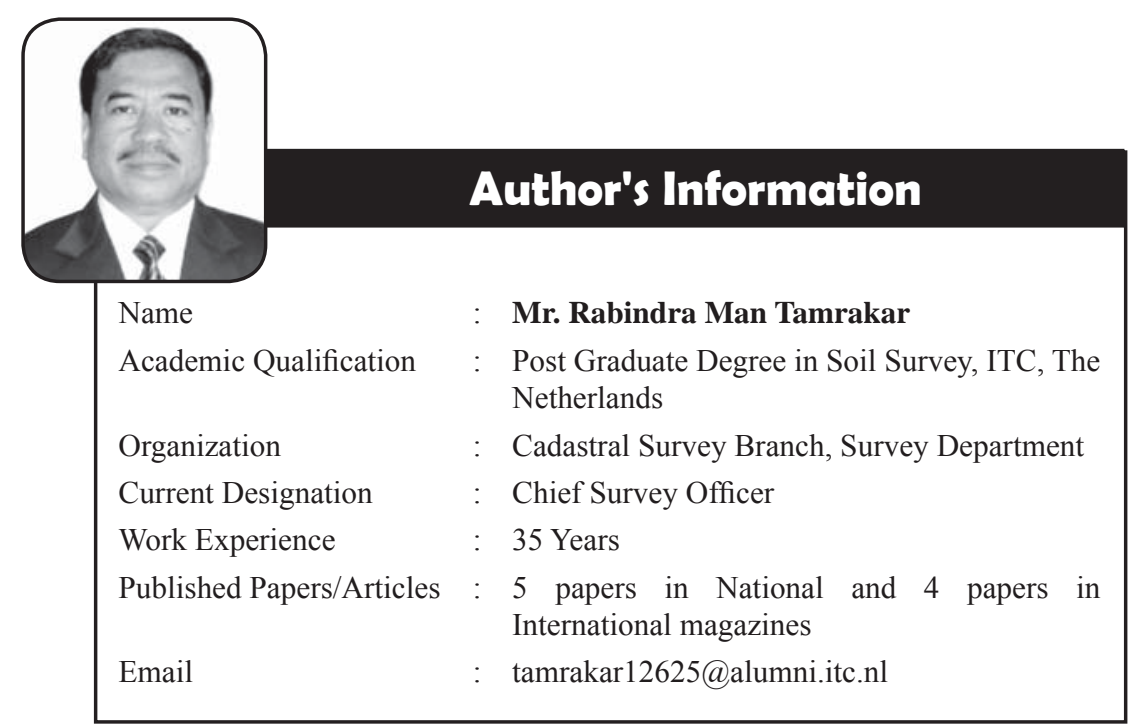

